\title{
Golgins: coiled-coil-rich proteins associated with the Golgi Complex
}

\author{
Edward K.L. Chan ${ }^{1}$ \\ W.M. Keck Autoimmune Disease Center, Department of Molecular and Experimental Medicine, The Scripps Research Institute, 10550 N orth Torrey Pines Road, La Jolla, \\ California, 92037 \\ Tel: 619-784-8250 Fax: 619-784-2131 \\ E-mail:echan@scripps.edu
}

Marvin J . Fritzler

Departments of Medicine and Medical Biochemistry, University of Calgary, 3330 Hospital Dr. N.W., Calgary, Alberta, Canada, T2N 4N I E-mail: fritzler@acs.ucalgary.ca

\begin{abstract}
Autoantibodies directed against self-antigens are characteristic features of a number of human diseases. In systemic rheumatic diseases, these include antibodies that react with extracellular molecules; the cell membrane; nuclear and cytoplasmic components. Our laboratories have been interested in understanding autoimmune responses in systemic lupus erythematosus and related disease states and using human autoantibody as molecular probes in studying the cell biology of target antigens. This review summarizes our research efforts in dissecting the autoimmune response to the Golgi complex via expression cloning using human autoantibodies. We have cloned 4 of 5 known Golgi autoantigens that are referred to as golgin-95/GM130, golgin-97, golgin-160/GCP170, and golgin-245, respectively based on their molecular weights. The fifth is giantin, also known as macrogolgin or GCP372. Interestingly, the amino acid sequences deduced for all Golgi autoantigens indicate that they are proteins with predominantly coiled-coil domains and non-alpha helical domains at the $\mathrm{N}$ - and $\mathrm{C}$-termini. The current postulate is that these coiled-coil rich proteins like golgin-95/GM130 form intermolecular complexes with a docking protein p115 that has been shown to be important for Golgi vesicular traffic. An alternative nonexclusive hypothesis is that these coiled-coil rich proteins are the components of the "strings" that are important in linking and guiding vesicles in intercisternae traffic. How this family of coiled-coil proteins and their complexes become autoimmune targets remains to be determined.
\end{abstract}

Patients with certain autoimmune diseases are characterized by the spontaneous occurrence of autoantibodies directed against a variety of tissue antigens (Tan, 1989). These include cell membrane components such as hormones and hormone receptors, immunoglobulins, proteins involved in fibrinolysis, complement proteins, and intracellular cytoplasmic and nudear components. Some of the target antigens are tissue specific, while others are variably expressed in differentiated and undifferentiated tissues. The studies of many intracellular autoantigens illustrate a number of important features concerning the clinical importance of human autoantibodies. First, certain autoantibodies seem to be restricted in one or a few diseases and, therefore, have useful diagnostic and prognostic implications. Second, patterns of end organ involvement are sometimes related to the presence of certain autoantibodies suggesting that they may have pathogenic significance.

An equally important outcome of studies of autoantigens has been the tremendous increase in our understanding of their molecular and cell biology (Tan, 1989; Tan et al., 1988). First, the majority of autoantibodies studied have been shown to bind to highly conserved determinants on ubiquitous cellular proteins. Second, most of the autoantibodies associated with systemic rheumatic diseases are often directed to functional macromolecules rather than to structural components. These indude histones, DNA and HMG of the nucleosome, several proteins of the small nudear ribonucleoprotein (snRNP) complex, various components of the mitotic apparatus induding centrosomes, kinetochore and centromere (CENPS) components, components of the nudeolus and the nudear membrane. Third, where systems are amenable to testing, it has been shown that the autoantibodies are able to inhibit the cellular functions served by the antigens. Examples include the inhibition of aminoacylation of tRNAs; the relaxation of supercoiled DNA; inhibition of precursor mRNA splicing; and the transcription of ribosomal RNA. Taken together, these observations suggest that the conserved epitopes recognized by human autoantibodies are often the functional or active sites of these intracellular proteins.

The study of human autoantibodies and their use as probes of cell structure and function has had an important impact on the disciplines of molecular and cell biology (Tan, 1991). For immunologists, one of the interesting objectives is the identification of macromolecules and organelles, such as the Golgi complex, that are targets of the autoimmune response. For cell biologists, attempts to unravel cellular events can be enhanced by the availability of specific autoantibody probes.

\section{The Golgi compartment}

In 1898, exactly 100 years ago, Camillio Golgi described a novel intracellular network which now bears his name (Golgi, 1898). The Golgi complex is an elaborate cytoplasmic organelle that has a prominent function in the processing, transporting, and sorting of intracellular proteins (reviewed in Gonatas, 1994; Mellman, 1995; Nilsson and Warren, 1994). Structurally, the Golgi complex is localized in the perinudear region of most mammalian cells and is characterized by stacks of membrane-bound cisternae as well as a functionally distinct trans- and cis-Golgi networks (TGN, CGN, Figure 1). It is proposed that the sorting functions of the Golgi complex are performed in TGN and CGN while the processing functions take place in the cis-, medial-, and transcompartments (Mellman and Simons, 1992). The intracellular transport of newly synthesized proteins requires directed movement from the endoplasmic reticulum (ER), via transport vesicles to the cis-, medial- and trans-compartments of the Golgi complex, and in some cases, to the plasma membrane (Banfield et al. 1994; Farquhar and Palade, 1981; Griffiths et al., 1989; Mellman, 1995; Nilsson and Warren, 1994; Rothman and Orci, 1992). Coatomer proteins COPIcoated vesicles are currently understood to mediate this anterograde transport across the intervening cisternae (Rothman, 1994; Schekman and Orci, 1996). Protein transport through the Golgi complex is mediated by small vesicles budding from a donor membrane and are targeted to, and

\footnotetext{
1 Corresponding author
} 
fused with, an acceptor membrane (Rothman and Orci, 1992). Transport vesicles are known to move towards the TGN and are also hypothesized to move in the 'retrograde' direction to the CGN via the coat protein complex (coatomer proteins, e.g. ß-COPs, ref. (Banfield et al., 1994; Barlowe et al., 1994; Duden et al., 1991; Orci et al., 1997; Pelham, 1994; Seaman and Robinson, 1994; Serafini et al., 1991; Waters et al., 1991). The pathways for the vesicular transport are shown schematically in Figure 1 and are thought to be important for the recycling of these membranous structures. The signals that control the vesicular traffic are poorly understood although it is known that intracellular microtubules are important components (Kreis, 1990; Mizuno and Singer, 1994). Other proteins of the Golgi complex believed to play a role indude families of proteins such as the adaptins (Pearse and Robinson, 1990), GTP-binding proteins (Jena et al., 1994; Martinez et al., 1994; Nuoffer et al., 1994; Oka and Nakano, 1994; Pfeffer, 1994), ADP ribosylation factors (ARFs) (Stearns et al., 1990), and resident enzymes (reviewed in (Farquhar, 1985; Nilsson and Warren, 1994). A rat peripheral membrane protein p115/ TAP has been identified as a component necessary for intra-Golgi transport (Barroso et al., 1995; Waters et al., 1992) and is proposed to be the mammalian homolog of Usol a protein required for endoplasmic reticulum to Golgi vesicular transport in Saccharomyces cerevisiae (Sapperstein et al., 1995).

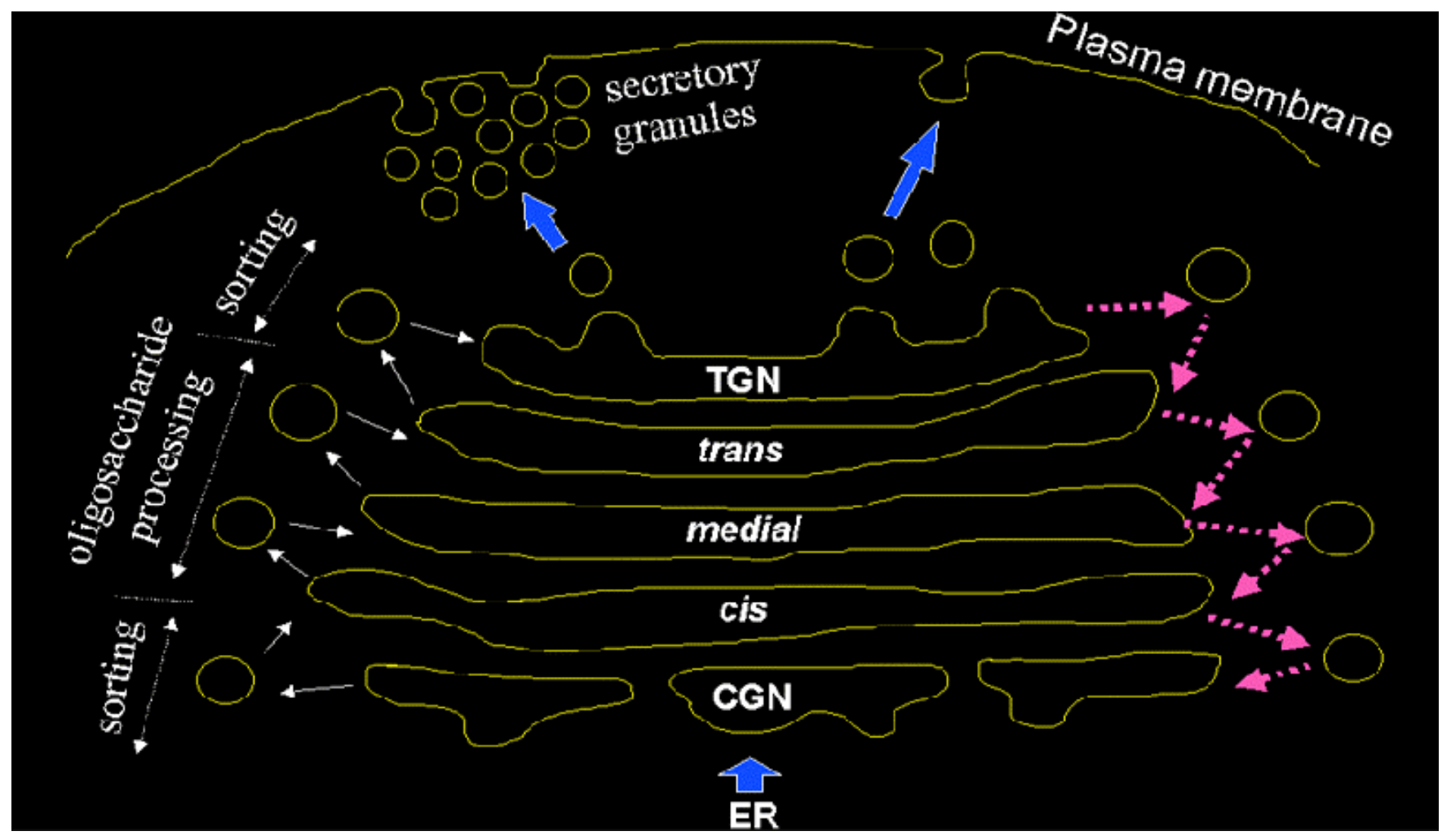

Figure 1. Golgi compartments and function. Some proteins are transported to the cell surface after synthesis at the endoplasmic reticulum (ER), sorting, and processing in the Golgi complex. The trans-Golgi network (TGN) and cis-Golgi network (CGN) are responsible for protein sorting via vesicle transport from ER to CGN and also in retrograde direction. In contrast, granins are sorted though the TGN and stored in secretory granules. Some granins are known to be proteolytically processed and secreted to extracellular space.

\section{Autoantigens of the Golgi compartment}

Autoantibodies directed against the Golgi complex were first identified in the serum of a Sjögren's syndrome (SS) patient with lymphoma (Rodriguez et al., 1982). Several isolated reports have described anti-Golgi antibodies in systemic rheumatic diseases induding SS and systemic lupus erythematosus patients (Blaschek et al., 1988; Fritzler et al., 1984; Hong et al., 1992; Kooy et al., 1994; Kooy et al., 1992; Renier et al., 1994; Rodriguez et al., 1982; Rossie et al., 1992), and in a variety of other disease conditions including idiopathic Raynaud's phenomenon (Gentric et al., 1990), idiopathic cerebellar ataxia (Fritzler et al., 1993; Gaspar et al., 1988), active Wegener's granulomatosis (Mayet et al., 1991), paraneoplastic cerebellar degeneration (Greenlee et al., 1988; Hida et al., 1994), stiff man syndrome (Butler et al., 1993), and viral infections including the Epstein Barr virus (EBV) (Huidbuchel et al., 1991), hepatitis B (Funaki et al., 1996), and the human immunodeficiency virus (HIV) (Gentric et al.,
1991). Immunoblotting and immuno precipitation studies have shown that there are heterogeneity of reactivities among anti-Golgi sera with at least 14 different Golgi complex autoantigens ranging from 35 to 260 kDa (Kooy et al., 1994; Renier et al., 1994). Immunofluorescence studies suggest that, like many other autoantigens, Golgi autoantigens are evolutionarily conserved and autoantibodies are able to recognize homologous proteins across species (Fritzler et al., 1993).

Within the last several years, our laboratories and others have cloned and identified five novel Golgi autoantigens (Table 1, Figure 2). This has been achieved primarily by expression cloning using human autoantibody probes. These are referred to as golgin-95 (GM 130), golgin-97, golgin-160, golgin-245 (p230), and giantin/ macrogolgin/ GCP372 respectively based on their molecular weights estimated from SDS-PAGE under denaturing condition. Interestingly, the amino acid sequences deduced for all golgins show that these proteins are 
composed of predominantly $\alpha$-helical coiled-coils except for the $\mathrm{N}$ - and C-terminal domains (Figure 4 and 5). The potential implication is that these Golgi proteins may have common biochemical characteristics that are responsible for inducing autoimmune response in certain disease states.

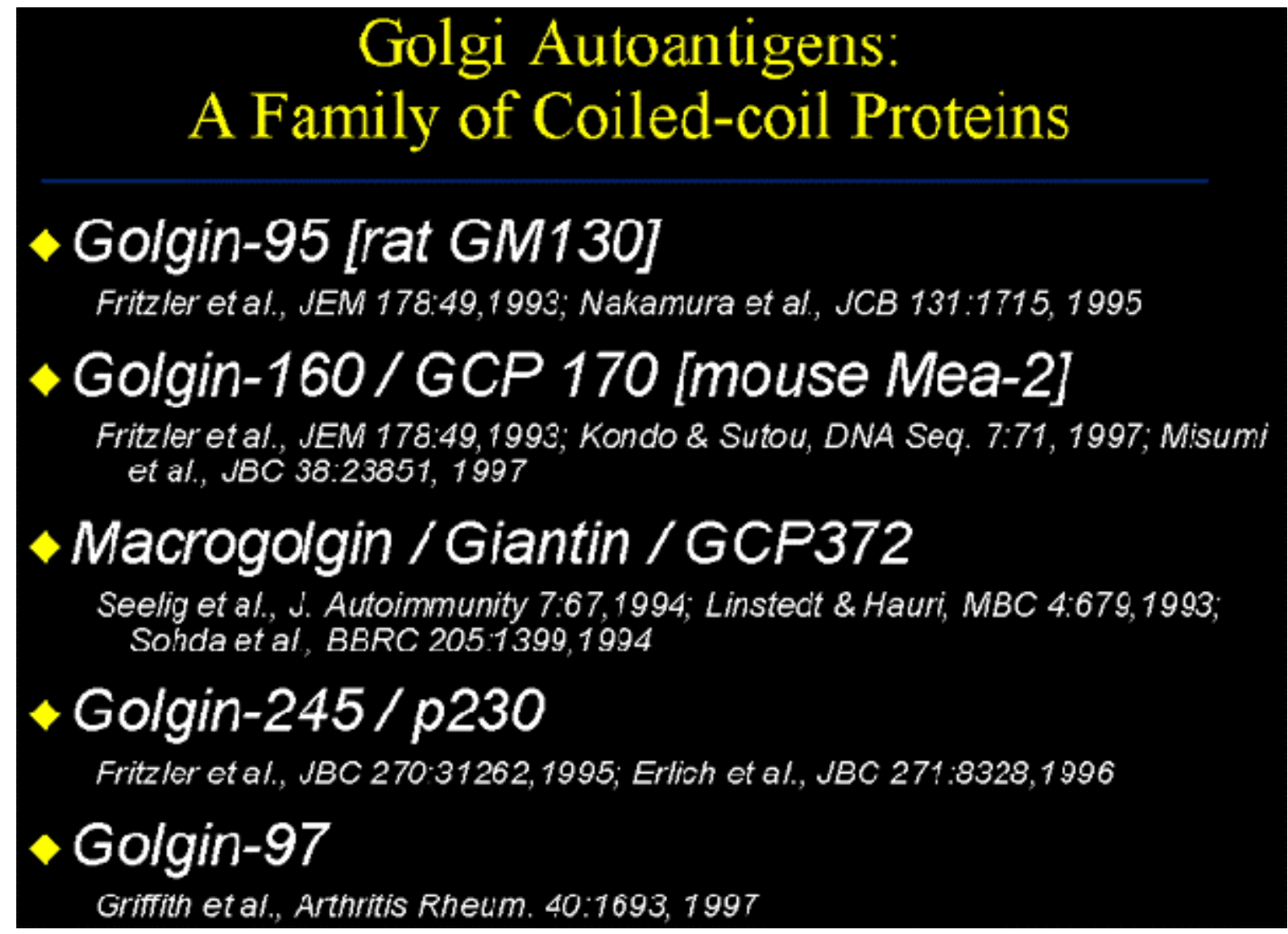

Figure 2. A list of Golgi coiled-coil protein autoantigens.

\section{Golgin-95/ GM130 and golgin-160/ GCP170}

The first two Golgi complex autoantigens were cloned in our laboratory using autoantibodies from a systemic lupus erythematosus patient (Table 1, Figure 3). These Golgi complex autoantigen cDNAs encode proteins of 95 and $160 \mathrm{kDa}$, and thus termed golgin-95 and golgin-160 respectively (Fritzler et al., 1993). Sequence analysis showed that golgin-95 and golgin-160 are composed of $\alpha$-helical coiled-coil domains sharing $43 \%$ overall sequence similarity and, therefore, may be functionally related proteins (Figure 4). Subsequent work from the isolation of rat liver Golgi matrix proteins, Nakamura et al (Nakamura et al., 1995) have shown that a $130 \mathrm{kDa}$ protein (GM130) may be the rat homolog of golgin-95. Our recent data confirmed that a $\sim 130 \mathrm{kDa}$ protein is detected in Hela cells using antibody to the previously observed 95kDa protein; thus our new data is consistent with the mol wt reported for GM 130 and the $95 \mathrm{kDa}$ protein was most likely a degradation product of GM130. A recent report showed that the N-terminal 73 amino acid residues of GM 130 interacts with the veside docking protein p115 and therefore may play a role in vesicular traffic between ER and Golgi stacks (Nakamura et al., 1997). In addition, the same laboratory reported that GM130 also interact strongly with GRASP65, a Golgi reassembly and stacking protein of $65 \mathrm{kDa}$ involved in the reformation of Golgi Complex after mitotic cell division (Barr et al., 1997).

A mouse testis protein known as Male-Enhanced Antigen-2 (Mea-2) originally identified with a monodonal histocompatibility $Y(H-Y)$ antibody was cloned and found to be highly homologous to human golgin-160 (Kondo and
Sutou, 1997). Although condusive data is not presented some role for golgin-160 in spermatogenesis is postulated based on the high level of expression of this gene in testis. Recently, the laboratory of Ikehara (Misumi et al., 1997) reported the doning of a full-length CDNA by extending from our earlier reported partial sequence of golgin-160. The group of Ikehara has named this protein GCP170 based on their estimated mol wt for this protein. It should be noted that the full-length protein contains an additional 160 proline-rich amino acids at the $\mathrm{N}$-terminus compared to Mea-2. Based on these observations, Misumi et al (Misumi et al., 1997) postulated the full-length protein has an N-terminal globular head, a long stalk composed of coiled-coil domains, and a C terminal short tail. It was also shown that GCP170 is localized to the cytoplasmic face of the Golgi membrane but not associated with -COP subunits of coatomers.

\section{Giantin/ macrogolgin/ GCP372}

The third autoantigen of the Golgi complex was identified by Seelig et $a$ l as macrogolgin (Seelig et al., 1994a). It was so named because of its large size (376kDa) and subsequent studies showed that macrogolgin is identical to a previously described large protein known as giantin (Linstedt and Hauri, 1993; Seelig et al., 1994b). In 1994 Ikehara and his colleagues reported a 372kDa Golgi complex autoantigen known as GCP372 (Sohda et al., 1994). When sequence alignments were performed, it was apparent that GCP372 has an extra 5 amino acids (QLSSM) "inserted" at residue 215 of 
the giantin amino acid sequence. Thus GCP372 could be derived from an alternatively spliced mRNA transcribed from the same gene as giantin/ macrogolgin. This same laboratory (Toki et al., 1997) recently reported the cloning of the rat homolog GCP364 and, in agreement with other earlier studies, concluded that giantin is anchored to the Golgi membrane via C-terminal hydrophobic domain with the coiled-coil domain extending to the cytoplasm (Figure 5); it is also postulated that this molecule may be involved in the formation and/ or maintenance of the Golgi structure. Recently, Sonnichsen et al (Sonnichsen et al., 1998) proposed that giantin interacts with p115 which in turn binds to GM 130 on Golgi membranes to promote vesicle traffic.
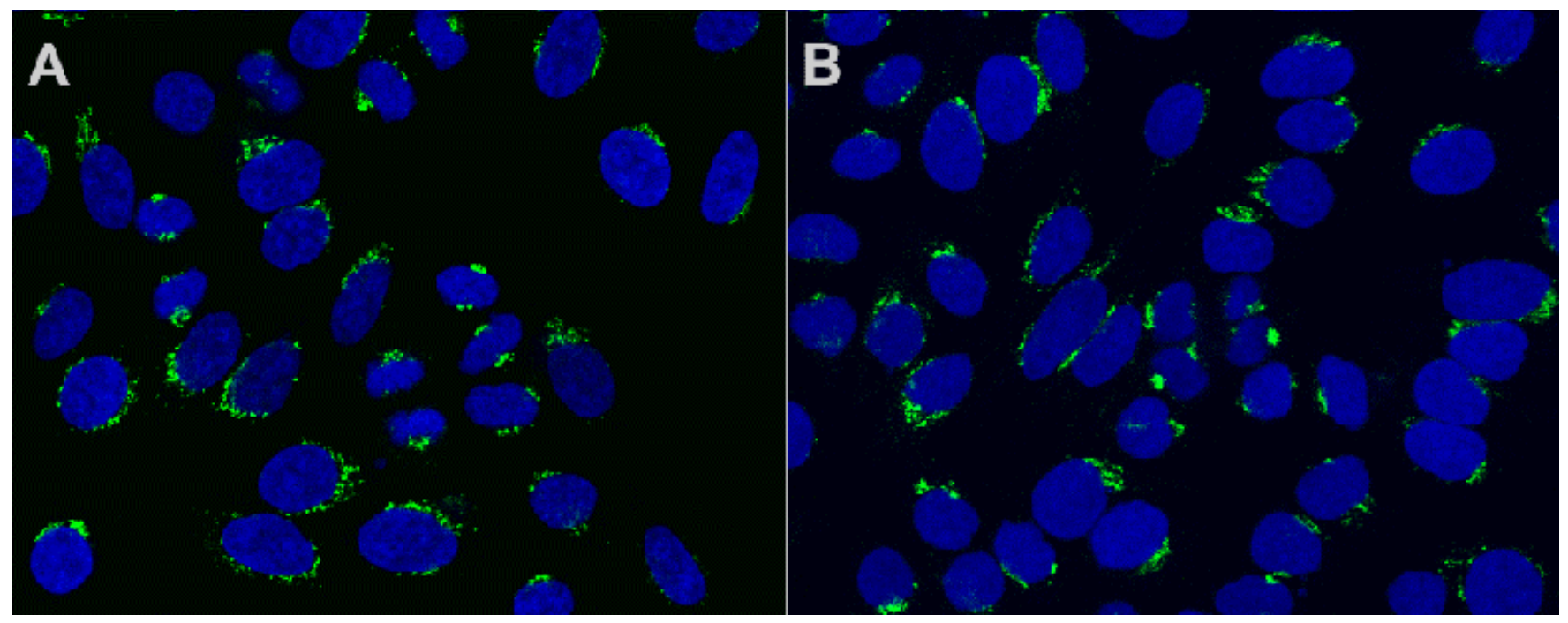

Figure 3. Indirect immunofluorescence detection of Golgi Complex in human HEp-2 cells. (A) rabbit anti-golgin-95/ GM 130 antibody. (B) rabbit anti-golgin-160 antibody. Nuclei were counter stained with DNA stain TROPO.

\section{Golgin-245/ p230}

Using a serum from a Sjögren's syndrome patient who had glomerulonephritis, the fourth golgin doned was a $245 \mathrm{kDa}$ protein, named golgin-245 (Fritzler et al., 1995). This protein was also characterized by a dominant coiled-coil domain and a granin signature motif found in a family of proteins known as granins. Granins are acidic proteins present in the secretory granules of a wide variety of endocrine and neuroendocrine cells. About the same time, another group described the nudeotide sequence from a previously reported a $230 \mathrm{kDa}$ Golgi complex autoantigen (p230) which is now known to be identical to golgin-245 (Erlich et al., 1996; Kooy et al., 1992). The study of p230 described alternatively spliced products suggesting that there may be further heterogeneity of this Golgi complex antigen (Erlich et al., 1996). A third group of investigators has recently reported the doning of the same protein using the serum from a patient with hepatitis $B$ (Funaki et al., 1996).

\section{Golgin-97}

The fifth Golgi autoantigen cDNA cloned with the serum from another Sjögren's syndrome patient was shown to encode a protein of 97kDa (golgin-97). Like golgin-245, golgin-97 has a predominant coiled-coil domain and a granin signature sequence that implicates its potential role associated with secretory granules. Among all the cloned Golgi complex autoantigens analyzed to date, golgin-97 appears to be the most common target associated with Sjögren's syndrome (Griffith et al., 1997). Although anti-Golgi autoantibodies are rare in Sjögren's syndrome patients, their detection may represent a subgroup of patients with interesting defects associated with Golgi function. Given that the sera used for the cloning of both golgin-245 and golgin-97 came from patients with SS and the existence of other reports of anti-
Golgi antibodies detected in patients with SS, it is intriguing to consider that these autoantibody-autoantigen systems play a significant role in the secretory defects in Sjögren's exocrine glands (Table 1).

\section{Coiled-coil domains of golgins}

The golgins are related as they have similar overall secondary structures as predicted by analysis programs such as COILS (Lupas et al., 1991) and PAIRCOIL (Berger et al., 1995). Figures 4 and 5 show the prediction of coiled-coil domains calculated by COILS for each of the five Golgi autoantigens. It is interesting that the golgins also show significant sequence similarity to several cytoskeleton-related proteins including kinesin (Bloom and Brashear, 1989), the 150 kD dyneinassociated protein (Holzbaur et al., 1991), the myosin family proteins (heavy chain myosin, tropomyosin), and desmin. Kinesin, a microtubulestimulated ATPase (Bloom et al., 1988; Kuznetsov and Gelfand, 1986), has been reported to be a motor for microtubule-mediated Golgi-to-ER membrane traffic (Lippincott-Schwartz et al., 1995). In support of this observation, it has been demonstrated that antibodies to kinesin and myosin bind to the Golgi complex (Fath and Burgess, 1993; Fath and Burgess, 1994; Marks et al., 1994). To extend the comparison, golgin-160 and macrogolgin have sequence similarity to the yeast cytoskeleton-related protein Usol, a yeast protein which is required for protein transport from the endoplasmic reticulum to the Golgi apparatus (Nakajima et al., 1991).

The human autoimmune response to golgins appears to be highly specific as many anti-Golgi sera react with only one of these autoantigens. It is therefore unlikely that the immune response is merely directed to cross-reactive the coiled-coil region in these molecules. In addition, coiled-coil domains have been noted in many other non-Golgi autoantigens 
induding nuclear mitotic apparatus protein NuMA (Andrade et al., 1996; Price et al., 1984), lamin B (Chou and Reeves, 1992; Konstantinov et al., 1996; Pollard et al., 1990), myosin heavy chain (von Muhlen et al., 1995), 52 kDa SS-A/ Ro (Buyon et al.,
1994; Chan et al., 1991), and 70/ 80 kDa Ku antigens (Chou et al., 1992; Reeves et al., 1991).

\section{Coiled-coil domains in golgins}

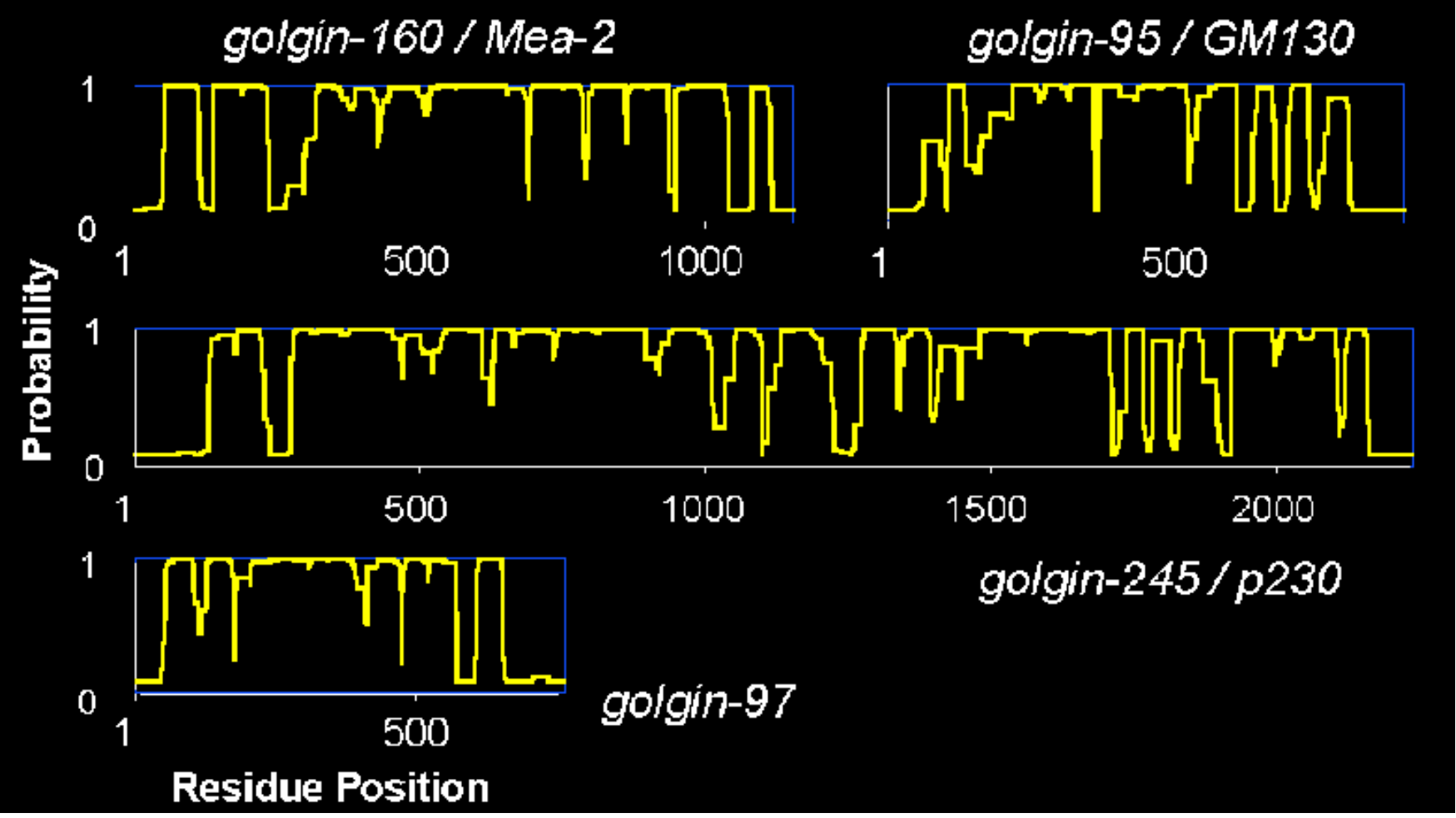

Figure 4. Coiled-coil domains of golgin-95/ GM 130, golgin-97, golgin-160/ Mea-2, and golgin-245. Each macromolecule is depicted as a plot of probability for the formation of coiled-coils calculated by the COILS program (Lupas et al., 1991).

\section{Granin signature in golgin-97 and golgin-245}

Granins are a family of acidic proteins present in the secretory granules of a wide variety of endocrine and neuroendocrine cells (Huttner et al., 1991; Simon and Aunis, 1989). Two consensus sequences have been reported. The granin 1 signature is located at the carboxyl terminus of the proteins and has been identified in all granin family proteins with the exception of murine secretogranin 2. The second consensus sequence, granin 2 , has been described in chromogranin $A$ and $B$ and is characterized by two cysteine residues bound together near the amino terminus of the protein. The acidic charge of these proteins has been attributed to high content of glutamic and aspartic acid. The function of these proteins or these signatures has not been dearly defined but current evidence suggests that they function in modulator-processing or packaging of neuropeptides. In addition, granins such as chromogranins and secretogranins are precursors that are proteolytically processed to biologically active secretory peptides (Natori and Huttner, 1994).

Decapeptides ESLALEELEL and ESLGKMEQEL corresponding to amino acids 388-397 in golgin-245 and amino acids 193-202 in golgin-97 were identified as a granin 1 'signature' which has the consensus pattern $\{D E\}\{S N\} L-$ \{SAN \} X(2) \{DE \}XEL (Huttner et al., 1991; Simon and Aunis, 1989). The predicted isoelectric points ( $\mathrm{pl}$ ) for golgin-245 and golgin-97 are 5.15 and 5.09 respectively which are similar to those reported for granins (pl 4.9-5.6). The anionic pls are consistent with the high content of glutamic and aspartic acid of these proteins. Golgin-245 has 17\% and 4\% while golgin-97 has $14 \%$ and $3 \%$ of glutamic and aspartic acid respectively. These features are consistent with those reported for granins. Recent review of available golgin-95/ GM 130 and golgin160/ GCP170 sequences showed no evidence for granin signature even when one mismatch is allowed. The significance of identifying granin signature may become apparent when immuno histocytochemical data is available for golgin-97 and golgin-245 at the electron microscopy level.

\section{Proposed function for golgins}

The observation that all Golgi complex autoantigens doned to date have predominantly central rod-like -helical coiled-coil structures and non-helical termini may be a due to their function. Recent publication by Orci, Perrelet and Rothman (Orci et al., 1998) proposes a "string theory" for the organization of Golgi vesides primarily based on their electron microscopy and freeze-fracture analysis of Golgi fractions purified from Chinese hamster ovary cells. The interpretation is that transport vesicles remain locally within the Golgi stack during their lifetime, near their origin, favoring a processive pattern of transport in which vesicles transfers occur preferentially between adjacent cisternae in the stack (Orci et al., 1998). The proposed theory accounts for the processive transport by postulating that vesicles are linked by "strings" which will restrict and keep the vesicles in close 
proximity. It is highly interesting and, of course, entirely reasonable to propose that these strings are composed of macromolecules rich in coiled-coil domains like GM 130 and giantin (Orci et al., 1998). The string theory postulates a predominate role for the coiled-coil rich Golgi proteins in holding transport vesicles in place. An additional function for this family of proteins may be in guiding vesicular traffic via specific interactions programmed into individual members of the coiled-coil rich protein family. Recent studies by Warren and his colleagues demonstrated the interaction of p115 with giantin and GM130 and thus p115 may serve as a bridge for COPI vesicles and Golgi membrane (Sonnichsen et al., 1998). In addition, the data from the same laboratory suggest that protein like golgin-95/ GM130 are directly associated with
GRASP65, which is important in the stacking of Golgi cisternae (Barr et al., 1997).

In summary, based on molecular sequence data, several Golgi autoantigens are defined as proteins rich in $\alpha$-helical coiledcoil domains with non-helical termini. These represent a subfamily of proteins that may play structural roles in supporting vesicles associated with the Golgi complex as well as stacking of Golgi cisternae. The rod domains are likely to participate in self-association as well as interaction among different family members. Their roles in vesicular traffic may soon become apparent as they are being actively investigated in many laboratories.

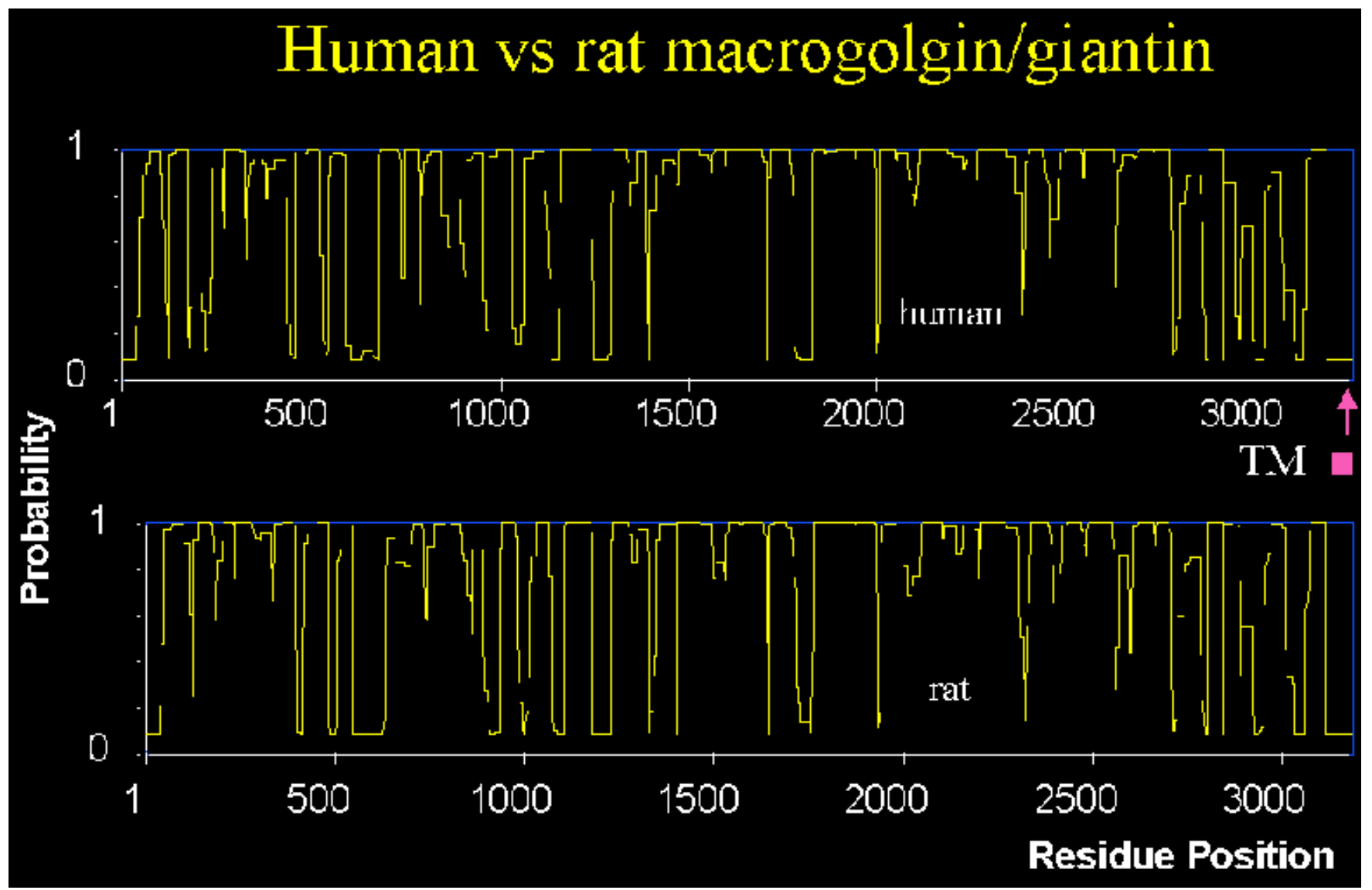

Figure 5. Comparison of coiled-coil domains of human and rat macrogolgin/ giantin. The probability for the formation of coiled-coils is calculated by the COILS program (Lupas et al., 1991). A transmembrane (TM) hydrophobic region at the Cterminus is postulated to be responsible for anchoring giantin to Golgi membrane with much of the molecule extending to the cytoplasm.

Table 1: Features of Golgi complex autoantigens and disease link.

\begin{tabular}{|c|c|c|c|c|}
\hline Name & $\begin{array}{l}\text { Native protein } \\
\text { (kDa) }\end{array}$ & $\begin{array}{l}\text { Disease Screening } \\
\text { Antibody* }\end{array}$ & $\begin{array}{l}\text { GenBank } \\
\text { Accession } \\
\text { Number } \\
\end{array}$ & Reference \\
\hline golgin-95 & 130 & SLE/cerebellar ataxia & LO6147 & (Fritzler et al., 1993) \\
\hline golgin-160 & 160 & SLE/cerebellar ataxia & LO6148 & (Fritzler et al., 1993) \\
\hline macrogolgin/giantin & 376 & $\begin{array}{l}\text { Scleroderma and } \\
\text { Sjögren's syndrome }\end{array}$ & X75304 & $\begin{array}{l}\text { (Linstedt and Hauri, } \\
\text { 1993; Seelig et al., } \\
\text { 1994a) }\end{array}$ \\
\hline GCP372 & 372 & Rheumatoid arthritis & D25542 & (Sohda et al., 1994) \\
\hline golgin-245 & 245 & $\begin{array}{l}\text { Sjögren's syndrome \& } \\
\text { glomerulonephritis }\end{array}$ & U31906 & (Fritzler et al., 1995) \\
\hline $\mathrm{p} 230$ & 230 & Sjögren's syndrome & U41740 & (Erlich et al., 1996) \\
\hline
\end{tabular}




\begin{tabular}{lllll} 
golgin-97 & 97 & Sjögren's syndrome & U51587 & (Griffith et al., 1997) \\
Rat GCP364 & 364 & Rheumatoid arthritis & D25543 & (Toki et al., 1997) \\
\hline Ahbreviatins:
\end{tabular}

Abbreviations: SLE=systemic lupus erythematosus

*Diagnosis of patient whose antibody was used for screening cDNA library.

\section{Acknowledgment}

This is publication 11530-MEM from the Scripps Research Institute.

\section{References}

Andrade, L. E. C., Chan, E. K. L., Peebles, C. L., and Tan, E. M. (1996). Two major autoantigen-antibody systems of the mitotic spindle apparatus. Arthritis and Rheumatism 39: 1643-1653.

Banfield, D. K., Lewis, M. J., Rabouille, C., Warren, G., and Pelham, H. R. B. (1994). Localization of Sed5, a putative veside targeting molecule, to the cis-Golgi network involves both its transmembrane and cytoplasmic domains. Journal of Cell Biology 127: 357-371.

Barlowe, C., Orci, L., Yeung, T., Hosobuchi, M., Hamamoto, S., Salama, N., Rexach, M. F., Ravazzola, M., A mherdt, M., and Schekman, R. (1994). COPII: a membrane coat formed by Sec proteins that drive veside budding from the endoplasmic reticulum. Cell 77: 895-907.

Barr, F. A., Puype, M., Vandekerckhove, J., and Warren, G. (1997). GRASP65, a protein involved in the stacking of Golgi cisternae. Cell 91: 253-62.

Barroso, M., Nelson, D. S., and Sztul, E. (1995). Transcytosisassociated protein (TAP)/ p115 is a general fusion factor required for binding of vesicles to acceptor membranes. Proceedings of the National Academy of Sciences U.S.A. 92: 527-31.

Berger, B., Wilson, D., Wolf, E., Tonchev, T., Milla, M., and Kim, P. (1995). Predicting coiled coils by use of pairwise residue correlations. Proceedings of the $\mathrm{N}$ ational A cademy of Sciences USA 92: 8259-8263.

Blaschek, M. A., Pennec, Y. L., Simitzis, A. M., Le Goff, P., Lamour, A., Kerdraon, G., Jouquan, J., and Youinou, P. (1988). Anti-Golgi complex autoantibodies in patients with primary Sjogren's syndrome Scandinavian Journal of Rheumatology 17: 291-296.

Bloom, G. S., and Brashear, T. A. (1989). A novel 58-kDa protein associates with the Golgi apparatus and microtubules. Journal of Biological Chemistry 264: 16083-16092.

Bloom, G. S., Wagner, M. C., Pfister, K. K., and Brady, S. T. (1988). Native structure and physical properties of bovine brain kinesin and identification of the ATP-binding subunit polypeptide. Biochemistry 27: 3409-3416.

Butler, M. H., Solimena, M., Dirkx, R., Jr., Hayday, A., and De Camilli, P. (1993). Identification of a dominant epitope of glutamic acid decarboxylase (GAD-65) recognized by autoantibodies in stiff-man syndrome Journal of Experimental Medicine 178: 2097-106.

Buyon, J. P., Slade, S. G., Reveille, J., Hamel, J. C., and Chan, E. K. L. (1994). Autoantibody responses to the "native" 52-kD SSA/ Ro protein in neonatal lupus syndromes, systemic lupus erythematosus and Sjogren's syndrome. Journal of Immunology 152: 3675-3684.
Chan, E. K. L., Hamel, J. C., Buyon, J. P., and Tan, E. M. (1991). Molecular definition and sequence motifs of the 52-kD component of human SS-A/Ro autoantigen. Journal of Clinical Investigation 87: 68-76.

Chou, C. H., and Reeves, W. H. (1992). Recognition of multiple epitopes in the coiled-coil domain of lamin $B$ by human autoantibodies. Molecular Immunology 29: 1055-1064.

Chou, C.-H., Wang, J., Knuth, M. W., and Reeves, W. H. (1992). Role of a major autoepitope in forming the DNA binding site of the $p 70(\mathrm{Ku})$ antigen. Journal of Experimental Medicine 175: 1677-1684.

Duden, R., Griffiths, G., Frank, R., Argos, P., and Kreis, T. E. (1991). Beta-COP, a $110 \mathrm{kd}$ protein associated with nonclathrin-coated vesides and the Golgi complex, shows homology to beta-adaptin. Cell 64: 649-665.

Erlich, R., Gleeson, P. A., Campbell, P., Dietzsch, E., and Toh, B. H. (1996). Molecular characterization of trans-Golgi p230. A human peripheral membrane protein encoded by a gene on chromosome 6 p12-22 contains extensive coiled-coil alphahelical domains and a granin motif. Journal of Biological Chemistry 271: 8328-8337.

Farquhar, M. G. (1985). Progress in unraveling pathways of Golgi traffic. Annual Review in Cell Biology 1: 447-488.

Farquhar, M. G., and Palade, G. E. (1981). The Golgi apparatus (complex)-(1954-1981)-from artifact to center stage Journal of Cell Biology 9: 77s-103s.

Fath, K. R., and Burgess, D. R. (1993). Golgi-derived vesicles from developing epithelial cells bind actin filaments and possess myosin-I as a cytoplasmically oriented peripheral membrane protein. Journal of Cell Biology 120: 117-127.

Fath, K. R., and Burgess, D. R. (1994). Membrane motility mediated by unconventional myosin. Current Opinion in Cell Biology 6: 131-135.

Fritzler, M. J., Etherington, J., Sokoluk, C., Kinsella, T. D., and Valencia, D. W. (1984). Antibodies from patients with autoimmune disease react with a cytoplasmic antigen in the Golgi apparatus. Journal of Immunology 132: 2904-2908.

Fritzler, M. J., Hamel, J. C., Ochs, R. L., and Chan, E. K. L. (1993). Molecular characterization of two human autoantigens: Uniques CDNAs encoding 95- and 160-kD proteins of a putative family in the Golgi complex. Journal of Experimental Medicine 17: 49-62.

Fritzler, M. J., Lung, C. C., Hamel, J. C., Griffith, K., and Chan E. K. L. (1995). Molecular characterization of golgin-245: a novel Golgi complex protein containing a granin signature. Journal of Biological Chemistry 270: 31262-31268.

Funaki, T., Fujiwara, T., Hong, H. S., Misumi, Y., Nishioka, M., and Ikehara, Y. (1996). Identification and characterization of a $230-k D a$ Golgi-associated protein recognized by autoantibodies from a patient with HBV hepatitis. Cell Structure and Function 21: 63-72.

Gaspar, M. L.,, Marcos, M. A., Gutierrez, C., Martin, M. J., Bonifacino, J. S., and Sandoval, I. V. (1988). Presence of an 
autoantibody against a Golgi cisternal membrane protein in the serum and cerebrospinal fluid from a patient with idiopathic late onset cerebellar ataxia. Journal of Neuroimmunology 17: 287-299.

Gentric, A., Blaschek, M., Julien, C., Jouquan, J., Pennec, Y., Berthelot, J. M., Mottier, D., Casburn-Budd, R., and Youinou, P. (1991). Nonorgan-specific autoantibodies in individuals infected with type 1 human immunodeficiency virus. Clinical Immunology and Immunopathology 59: 487-494.

Gentric, A., Blaschek, M. A., Le Noach, J. F., Johanet, C., Jouquan, J., Lamour, A., Abuaf, N., Pennec, Y. L., and Youinou, P. (1990). Serological arguments for classifying Raynaud's phenomenon as idiopathic. Journal of Rheumatology 17: 1177-81.

Golgi, C. (1898). Sur la structure des cellules nerveuses. Archives Italiennes de Biologie 30: 60-71.

Gonatas, N. K. (1994). Contributions to the physiology and pathology of the Golgi apparatus. American Journal of Pathology 145: 751-761.

Greenlee, J. E., Brashear, H. R., and Herndon, R. M. (1988). Immunoperoxidase labelling of rat brain sections with sera from patients with paraneoplastic cerebellar degeneration and systemic neoplasia. Journal of Neuropathology and Experimental Neurology 47: 561-571.

Griffith, K. J., Chan, E. K. L., Lung, C. C., Hame, J. C., Guo, X., Miyachi, K., and Fritzler, M. J. (1997). Molecular cloning of a novel 97-kd Golgi complex autoantigen associated with Sjogren's syndrome. Arthritis and Rheumatism 40: 1693-702.

Griffiths, G., Fuller, S. D., Back, R., Hollinshead, M., Pfeiffer, S., and Simons, K. (1989). The dynamic nature of the Golgi complex. Journal of Cell Biology 108: 277-297.

Hida, C., Tsukamoto, T., Awano, H., and Yamamoto, T. (1994). Últrastructural localization of anti-Purkinje cell antibody-binding sites in paraneoplastic cerebellar degeneration. A rchives of Neurology 51: 555-558.

Holzbaur, E. L., Hammarback, J. A., Paschal, B. M., Kravit, N. G., Pfister, K. K., and Vallee, R. B. (1991). Homology of a $150 \mathrm{~K}$ cytoplasmic dynein-associated polypeptide with the Drosophila gene Glued. Nature 351: 579-583.

Hong, H. S., Morshed, S. A., Tanaka, S., Fujiwara, T., Ikehara, Y., and Nishioka, M. (1992). Anti-Golgi antibody in rheumatoid arthritis patients recognizes a novel antigen of 79 $\mathrm{kDa}$ (doublet) by western blot. Scandinavian Journal of Immunology 36: 785-792.

Huidbuchel, E., Blaschek, M., Seigneurin, J. M., Lamour, A., Berthelot, J. M., and Youinou, P. (1991). Anti-organelle and anti-cytoskeletal autoantibodies in the serum of Epstein-Barr virus-infected patients. Annals Medicine Interne.(Paris.) 142: 343-346.

Huttner, W. B., Gerdes, H. H., and Rosa, P. (1991). The granin (chromogranin/ secretogranin) family. Trends in Biochemical Science 16: 27-30.

Jena, B. P., Gumkowski, F. D., Konieckko, E. M., von Mollard, G. F., Jahn, R., and Jamieson, J. D. (1994). Redistribution of a rab3-like GTP-binding protein from secretory granules to the Golgi complex in pancreatic acinar cells during regulated exocytosis. Journal of Cell Biology 124: 43-53.

Kondo, M., and Sutou, S. (1997). Cloning and molecular characterization of CDNA encoding a mouse male-enhanced antigen-2 (Mea-2): a putative family of the Golgi autoantigen.
DNA Sequence - The Journal of Sequencing and Mapping 7: 71-82.

Konstantinov, K., von Mikecz, A., Buchwald, D., Jones, J., Gerace, L., and Tan, E. M. (1996). Autoantibodies to nuclear envelope antigens in chronic fatigue syndrome Journal of Clinical Investigation 98: 1888-1896.

Kooy, J., Toh, B. H., and Gleeson, P. A. (1994). Heterogeneity of human anti-Golgi auto-antibodies: reactivity with components from 35 to $260 \mathrm{kDa}$. Immunology and Cell Biology 72: 123-127.

Kooy, J., Toh, B. H., Pettitt, J. M., Erlich, R., and Gleeson, P. A. (1992). Human autoantibodies as reagents to conserved Golgi components. Characterization of a peripheral, 230-kDa compartment-specific Golgi protein. Journal of Biological Chemistry 26: 20255-20263.

Kreis, T. E. (1990). Role of microtubules in the organisation of the Golgi apparatus. Cell Motility and Cytoskeleton 15: 67-70.

Kuznetsov, S. A., and Gelfand, V. I. (1986). Bovine brain kinesin is a microtubule-activated ATPase. Proceedings of the National A cademy of Sciences USA 83: 8530-8534.

Linstedt, A. D., and Hauri, H. P. (1993). Giantin, a nove conserved Golgi membrane protein containing a cytoplasmic domain of at least $350 \mathrm{kDa}$. Molecular Biology of the Cell 4: 679-693.

Lippincott-Schwartz, J., Cole, N. B., Marotta, A., Conrad, P. A., and Bloom, G. S. (1995). Kinesin is the motor for microtubule-mediated Golgi-to-ER membrane traffic. Journal of Cell Biology 128: 293-306.

Lupas, A., Van Dyke, M., and Stock, J. (1991). Predicting coiled coils from protein sequences. Science 252: 1162-1164.

Marks, D. L., Larkin, J. M., and McNiven, M. A. (1994). Association of kinesin with the Golgi apparatus in rat hepatocytes. Journal of Cell Sciences 107: 2417-2426.

Martinez, O., Schmidt, A., Salamero, J., Hoflack, B., Roa, M., and Goud, B. (1994). The small GTP-binding protein rab6 functions in intra-Golgi transport. Journal of Cell Biology 127: 1575-1588.

Mayet, W. J., Hermann, E., Csernok, E., Knuth, A., Poralla, T., Gross, W. L., and Meyer zum Buschenfelde, K. H. (1991). A' human renal cancer line as a new antigen source for the detection of antibodies to cytoplasmic and nuclear antigens in sera of patients with Wegener's granulomatosis. Journal of Immunological Methods 143: 57-68.

Mellman, I. (1995). Enigma variations: protein mediators of membrane fusion. Cell 82: 869-872.

Mellman, I., and Simons, K. (1992). The Golgi complex: in vitro veritas? Cell 68: 829-840.

Misumi, Y., Sohda, M., Yano, A., Fujiwara, T., and Ikehara, Y. (1997). 'Molecular characterization of GCP170, a 170-kDa protein associated with the cytoplasmic face of the Golgi membrane. Journal of Biological Chemistry 272: 23851-8.

Mizuno, M., and Singer, S. J. (1994). A possible role for stable microtubules in intracellular transport from the endoplasmic reticulum to the Golgi apparatus. Journal of Cell Sciences 107: 1321-1331.

Nakajima, H., Hirata, A., Ogawa, Y., Yonehara, T., Yoda, K., and Yamasaki, M. (1991). A cytoskeleton-related gene, usol, is 
required for intracellular protein transport in Saccharomyces cerevisiae. Journal of Cell Biology 113: 245-260.

Nakamura, N., Lowe, M., Levine, T. P., Rabouille, C., and Warren, G. (1997). The vesicle docking protein p115 binds GM130, a cis-Golgi matrix protein, in a mitotically regulated manner. Cell 89: 445-55.

Nakamura, N., Rabouille, C., Watson, R., Nilsson, T., Hui, N., Slusarewicz, P., Kreis, T.' E., and 'Warren, G. (1995). Characterization of a cis-Golgi matrix protein, GM 130. Journal of Cell Biology 131: 1715-1726.

Natori, S., and Huttner, W. B. (1994). Peptides derived from the granins (chromogranins/ secretogranins). Biochimie 76 : 277-282.

Nilsson, T., and Warren, G. (1994). Retention and retrieval in the endoplasmic reticulum and the Golgi apparatus. Current Opinion in Cell Biology 6: 517-521.

Nuoffer, C., Davidson, H. W.., Matteson, J., Meinkoth, J., and Balch, W. E. (1994). A GDP-bound of rabl inhibits protein export from the endoplasmic reticulum and transport between Golgi compartments. Journal of Cell Biology 125: 225-237.

Oka, T., and Nakano, A. (1994). Inhibition of GTP hydrolysis by Sarlp causes accumulation of vesicles that are a functional intermediate of the ER-to-Golgi transport in yeast. Journal of Cell Biology 124: 425-434.

Orci, L., Perrelet, A., and Rothman, J. E. (1998). Vesicles on strings: morphological evidence for processive transport within the golgi stack. Proceedings of the National Academy of Sciences

USA 95: 2279-83.

Orci, L., Stamnes, M., Ravazzola, M., Amherdt, M., Perrelet, A., Sollner, T. H., and Rothman, J.' E. (1997). Bidirectional transport by distinct populations of COPI-coated vesides. Cell 90: 335-49.

Pearse, B. M., and Robinson, M. S. (1990). Clathrin, adaptors, and sorting. Annual Review of Cell Biology 6: 151-171.

Pelham, H. R. B. (1994). About turn for the COPs? Cell 79: 1125-1127.

Pfeffer, S. R. (1994). Rab GTPases: master regulators of membrane trafficking. Current Opinion in Cell Biology 6: 522526.

Pollard, K. M., Chan, E. K. L., Grant, B. J., Sullivan, K. F., Tan, E. M., and Glass, C. A. (1990). In vitro posttranslational modification of lamin $B$ cloned from a human T-cell line. Molecular and Cellular Biology 10: 2164-2175.

Price, C. M., McCarty, G. A., and Pettijohn, D. E. (1984). NuMA protein is a human autoantigen. Arthritis and Rheumatism 27: 774-779.

Reeves, W. H., Pierani, A., Chou, C.-H., Ng, T., Nicastri, C., Roeder, R. G., and Sthoeger, Z. M. (1991). Epitopes of the p70 and p80 (Ku) lupus autoantigens. Journal of Immunology 146: 2678-2686.

Renier, G., Rousselet, M. C., Carrere, F., Croue, A., Andre, C., Oksman, F., Chevailler, A., and Hurez, D. (1994). Golgi autoantibodies and autoantigens. Journal of Autoimmunity 7 : 133-143.
Rodriguez, J. L., Gelpi, C., Thomson, T. M., Real, F. J., and Fernandez, J. (1982). Anti-golgi complex autoantibodies in a patient with Sjogren syndrome and lymphoma. Clinical and Experimental Immunology 49: 579-586.

Rossie, K. M., Piesco, N. P., Charley, M. R., Oddis, C. V., Steen, V. D., Fratto, J., and Deng, J. S. (1992). A monoclonal antibody recognizing golgi apparatus produced using affinity purified material from a patient with connective tissue disease. Scandinavian Journal of Rheumatology 21: 109-115.

Rothman, J. E. (1994). Mechanisms of intracellular protein transport. Nature 372: 55-63.

Rothman, J. E., and Orci, L. (1992). Molecular dissection of the secretory pathway. Nature 355: 409-415.

Sapperstein, S. K., Walter, D. M., Grosvenor, A. R., Heuser, J. E., and Waters, M. G. (1995). p115 is a general vesicular transport factor related to the yeast endoplasmic reticulum to Golgi transport factor Usolp. Proceedings of the National Academy of Sciences U.S.A. 92: 522-6.

Schekman, R., and Orci, L. (1996). Coat proteins and veside budding. Science 271: 1526-33.

Seaman, M. N. J., and Robinson, M. S. (1994). Membrane traffic. Call for the COPs. Current Biology 4: 926-929.

Seelig, H. P., Schranz, P., Schroter, H., Wiemann, C., and Renz, M. (1994a). Macrogolgin--a new 376 kD Golgi complex outer membrane protein as target of antibodies in patients with rheumatic diseases and HIV infections. Journal of Autoimmunity 7: 67-91.

Seelig, H. P., Schranz, P., Schroter, H., Wiemann, C., Griffiths, G., and Renz, M. (1994b). M olecular genetic analyses of a 376kilodalton Golgi complex membrane protein (giantin). Molecular and Cellular Biology 14: 2564-2576.

Serafini, T., Stenbeck, G., Brecht, A., Lottspeich, F., Orci, L., Rothman, J. E., and Wieland, F. T. (1991). A coat subunit of Golgi-derived non-dathrin-coated vesicles with homology to the dathrin-coated veside coat protein beta-adaptin. Nature 349: 215-220.

Simon, J. P., and Aunis, D. (1989). Biochemistry of the chromogranin A protein family. Biochemistry Journal 262: 113.

Sohda, M., Misumi, Y., Fujiwara, T., Nishioka, M., and Ikehara, Y.'(1994). Molecular cloning and sequence analysis of a human 372-kDA protein localized in the Golgi complex. Biochemical and Biophysical Research Communication 205: 1399-1408.

Sonnichsen, B., Lowe, M., Levine, T., Jamsa, E., DiracSvejstrup, B., and Warren, 'G. (1998). A' Role for Giantin in Docking COPI Vesicles to Golgi Membranes. Journal of Cell Biology 140: 1013-21.

Stearns, T., Willingham, M. C., Botstein, D., and Kahn, R. A. (1990). A DP-ribosylation factor is functionally and physically associated with the Golgi complex. Proceedings of the National A cademy of Sciences USA 87: 1238-1242.

Tan, E. M. (1989). Antinudear antibodies: diagnostic markers for autoimmune diseases and probes for cell biology. Advances in Immunology 44: 93-151.

Tan, E. M. (1991). Autoantibodies in pathology and cell biology. Cell 67: 841-842. 
Chan, E.K.L. and Fritzler, M.J .

Tan, E. M., Chan, E. K. L., Sullivan, K. F., and Rubin, R. L. (1988). Antinudear antibodies (ANAs): diagnostically specific immune markers and clues toward the understanding of systemic autoimmunity. Clinical Immunology and Immunopathology 47: 121-141.

Toki, C., Fujiwara, T., Sohda, M., Hong, H. S., Misumi, Y., and Ikehara, Y. (1997). Identification and characterization of rat 364-kDa Golgi-associated protein recognized by autoantibodies from a patient with rheumatoid arthritis. Cell Structure and Function 22: 565-77.

von Muhlen, C. A., Chan, E. K. L., Peebles, C. L., Imai, H., Kiyosawa, K., and Tan, E. M. (1995). Non-muscle myosin as target antigen for human autoantibodies in patients with hepatitis C virus-associated chronic liver diseases. Clinical and Experimental Immunology 100: 67-74.

Waters, M. G., Clary, D. O., and Rothman, J. E. (1992). A novel $115-k D$ peripheral membrane protein is required for intercisternal transport in the Golgi stack. Journal of Cell Biology 118: 1015-26.

Waters, M. G., Serafini, T., and Rothman, J. E. (1991). 'Coatomer': a cytosolic protein complex containing subunits of non-clathrin-coated Golgi transport vesicles. Nature 349: 248251. 